City University of New York (CUNY)

CUNY Academic Works

\title{
ADDRESSING THE LEARNING LOSS DURING THE COVID-19 PANDEMIC THROUGH THE ADAPTATION OF VIRTUAL PLATFORMS
}

\author{
Nazrul I. Khandaker \\ cUNY York College \\ Anika Nawar Mayeesha \\ Dhaka University \\ Violeta Escandon Correa \\ Georgia Institute of Technology \\ Toralv Munro \\ Andrew Singh \\ cUNY York College
}

See next page for additional authors

\section{How does access to this work benefit you? Let us know!}

More information about this work at: https://academicworks.cuny.edu/yc_pubs/301

Discover additional works at: https://academicworks.cuny.edu

This work is made publicly available by the City University of New York (CUNY).

Contact: AcademicWorks@cuny.edu 


\section{Authors}

Nazrul I. Khandaker, Anika Nawar Mayeesha, Violeta Escandon Correa, Toralv Munro, Andrew Singh, Matthew Khargie, Ality Aghedo, Jasmin Budhan, Krishna Mahabir, and Belal A. Sayeed 


\section{ADDRESSING THE LEARNING LOSS DURING THE \\ COVID-19 PANDEMIC THROUGH THE ADAPTATION OF VIRTUAL PLATFORMS} NASA X⿻一𠃋十

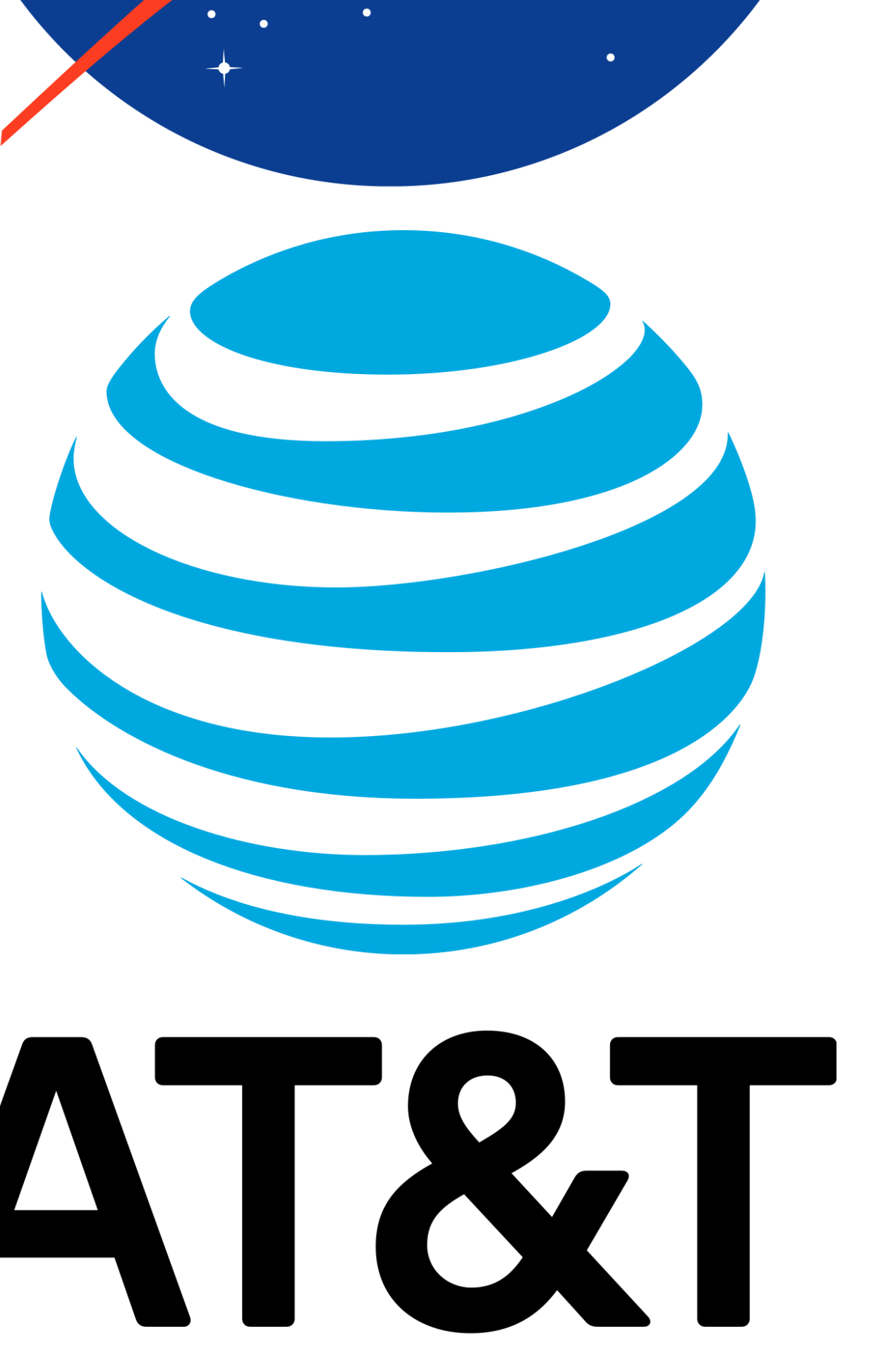

KHANDAKER, Nazrul, York College of CUNY, 9420 Guy R Brewer Blvd, AC-2F09, Jamaica, NY 11451-0001, MAYEESHA, Anika Nawar, Geology Department \& SPE Student Chapter, Dhaka University, Dhaka, 1000, Bangladesh, CORREA, Violeta Escandon, Georgia Institute of Technology, North Ave NW, Atlanta, GA 30332, MUNRO, Toralv, 10911 164th St Apt 1, Jamaica, NY 11433-2921, SINGH, Andrew, Earth and Physical Sciences, York College of CUNY, 9420 Guy R Brewer Blvd, AC-2F09, Jamaica, NY 11451-0001, KHARGIE, Matthew, CoEnterprise, 45 West, 36TH Street, New York City, NY 10018, AGHEDO, Ality, Environmental Science and Policy, Johns Hopkins University, Baltimore, Baltimore, NY 21218, BUDHAN, Jasmin, Tufts University, 419 Boston Ave,, Medford, MA 02155, MAHABIR, Krishna, Science and Robotics Dept., Grover Cleveland High School, 2127 Himrod Street, Ridgewood, NY 11385 and SAYEED, Belal A., Dewberry Geotechnical Company, New York, NY 10001
conEdison, inc.

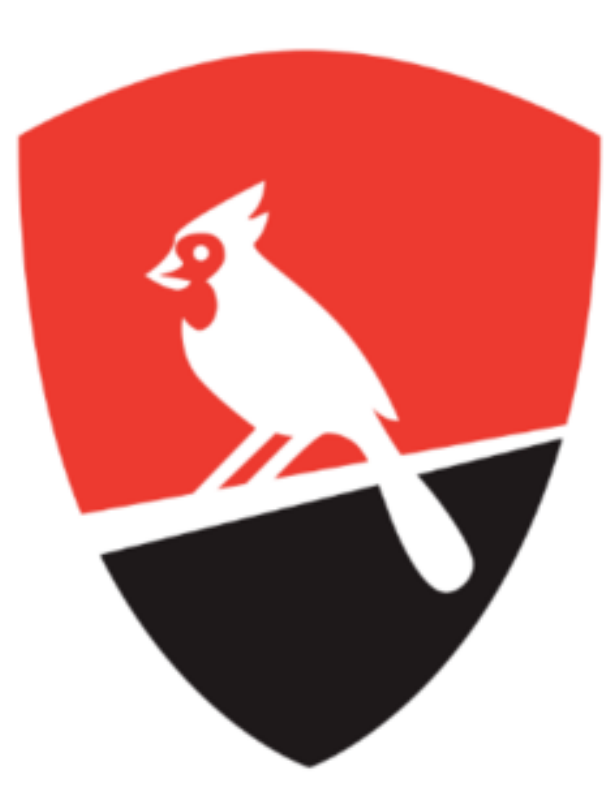

York College

\section{INTRODUCTION}

The York College-hosted NASA MAA (MUREP AEROSPACE ACADEMY) has always played a pivotal months, which was heightened during the pandemic.

Support from AT\&T, Con Edison and NASA enabled the MAA program at York College to offer a virtual STEM education with basic science and python-based concentration to 1000 plus underserved K1-12 students from the community last summer, including 160 high school students.

KEY TO THE OPERATIONAL SUCCESS Two factors made this endeavor fruitful:

1) Allowing additional time to engage in STEM lessons

2) increasing self-motivation to successfully accomplish assigned tasks.

Students built partnerships and resolved technical issues with the smaller class size.

MAA students normally receive more than three hours of uninterrupted STEM lessons, as opposed to less than 90 minutes of instruction time in math and science classes in their respective public schools.

STEM EDUCATION AND CONTINUITY Based on the successful outcome from the 2020 operation, York's NASA MAA will be continuing its peer mentoring initiative, with the goal to increase the scope and allow additional students to receive both academic and research taining during summer spring 2022

Applied mathematics including analytical geometry, trigonometry, number theories, and algebra, as well as offered to students (Image 1 through 6 ).

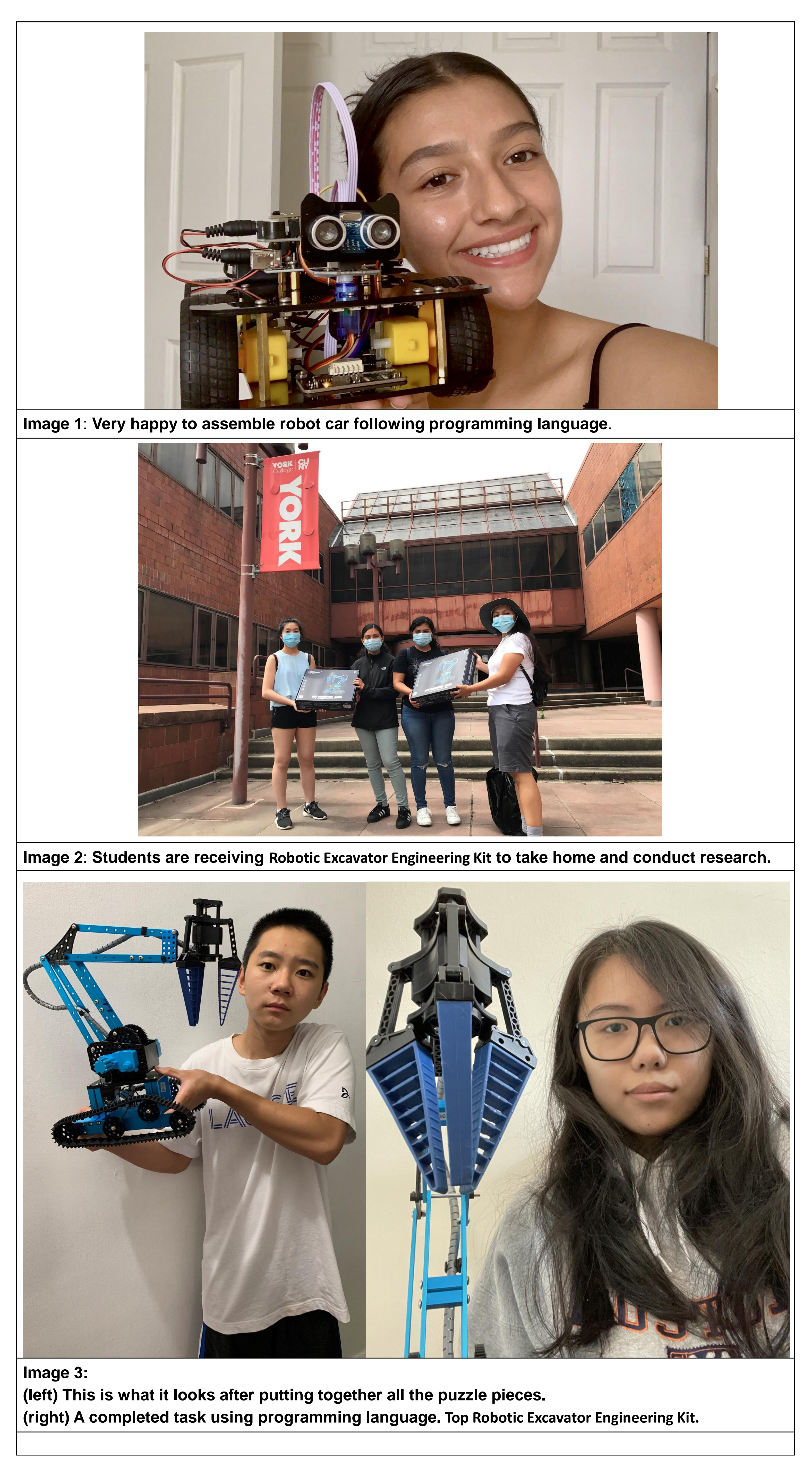

ENHANCED CURRICULUM ACTIVITIES The other notable pedagogical focus will be to provide meaningful connections with scientific vocabulary and how to communicate effectively.

Group or individual presentations will be used in classroom activities. Modified and newly structured math and science curricula will enable participating students to fully engage in an interactive learning environment through discussion, breakout sessions, and homework.

Individual math and science lessons are built on the best practices tailored down to the students' reach and are aimed at fostering teamwork and group learning.

\section{CONCLUSIONS}

It is very important for the MAA summer program to continue to offer evidenced-based STEM education to minority students and allow them to become knowledgeable, well informed, and ready to apply for internships and attend college focusing on STEM subjects.

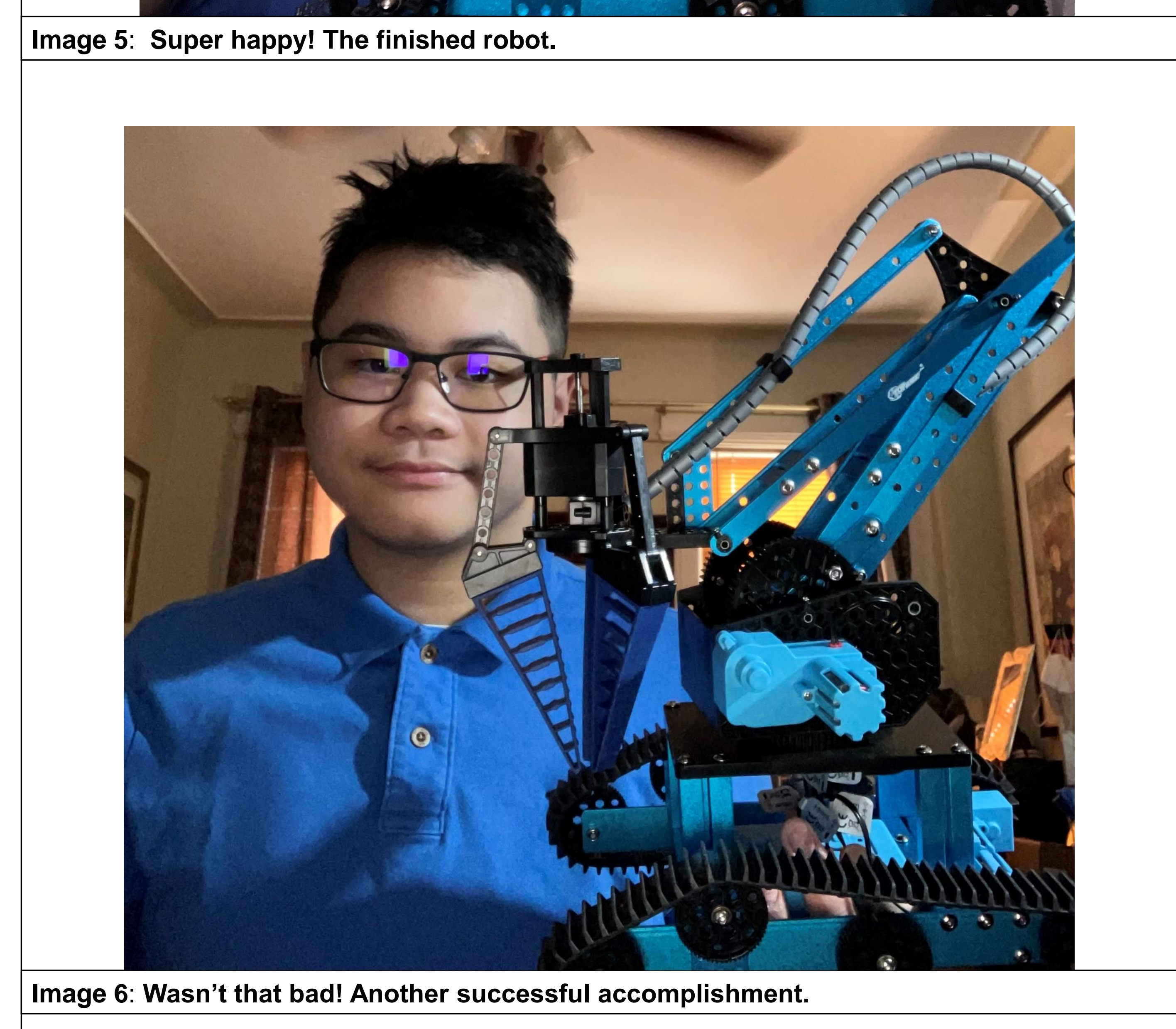

\section{ACKNOWLEDGEMENTS}

The authors greatly acknowledge the research opportunity provided by The City University of New York (CUNY) Research and Education Project Aerospace Academy) 2021 Program. research experience during the global COVID-19 pandemic.

\section{ABSTRACT}

Geological Society of America Abstracts with Programs. doi: 10.1130/abs/2021 AM-367121
Funding from AT\&T and ConEdison helped to support this 